\title{
STRATEGI ALOKASI BELANJA PEMERINTAH DAERAH DALAM MENINGKATKAN IPM DI PROVINSI JAMBI
}

\section{Strategy of Allocating the Government Expenditure to Increase HDI of Regencies and Towns in Jambi Province}

\author{
Fransisco $^{1}$, Muhammad Firdaus ${ }^{2}$, Sri Mulatsih ${ }^{2}$ \\ ${ }^{1}$ Staff Koperasi Korp Pegawai Negeri Sipil Provinsi Jambi. Email: fransvolution@gmail.com \\ ${ }^{2}$ Staff Pengajar Departemen Ilmu Ekonomi Fakultas Ekonomi dan Manajemen. IPB. Email: \\ firdausfemipb@yahoo.com, mulatsupardi@gmail.com
}

\begin{abstract}
The region finances of good management have impact of progressing on a area. This study aims to develop a strategy of allocating the government expenditure to increase HDI of Regencies and Towns in Jambi province using a GMM (Generalized Method of Moments) regression model. The variables used in the study are HDI (Human Development Index as endogenous variable), allocated spending in the economic sector, housing and public infrastructure, as well as health and education (exogenous variables). The study uses cross-section data of Regencies/Towns in Jambi and time series data of 2010 - 2015. The analysis showed that HDI and the allocated expenditure in the economic sectors, housing and public infrastructure, as well as education had a significant effect on the increase in HDI. The formulated strategy by using AHP (Analytical Hierarchy Process) suggests an allocation priority in education by improving competence, and in the field of economics and health by providing facilities and infrastructure.
\end{abstract}

Keyword: AHP, Panel Data, SYS GMM, Jambi

\section{ABSTRAK}

Pengelolaan keuangan daerah yang baik akan berpengaruh terhadap kemajuan suatu daerah. Penelitian ini bertujuan menyusun strategi alokasi belanja pemerintah dalam meningkatkan IPM Kabupaten dan Kota di Provinsi Jambi menggunakan model regresi GMM (Generalized Method of Moments). Variabel yang digunakan adalah IPM (variabel endogen), alokasi belanja sektor ekonomi, serta alokasi sektor perumahan dan penyediaan sarana prasarana umum, alokasi belanja sektor kesehatan dan alokasi belanja disektor pendidikan (variabel eksogen). Data yang digunakan ialah cross section Kabupaten/Kota di Jambi dan time series 2010-2015. Analisis menunjukkan bahwa IPM tahun sebelumnya, alokasi belanja sektor ekonomi tahun sebelumnya, serta alokasi sektor perumahan dan penyediaan sarana prasarana umum dan alokasi belanja sektor pendidikan berpengaruh signifikan terhadap peningkatan IPM. Perumusan strategi dengan menggunakan AHP diperoleh alokasi prioritas dibidang pendidikan melalui peningkatan kompetensi, dibidang ekonomi dan kesehatan melalui penyediaan sarana dan prasarana.

Kata Kunci : AHP, Panel Data, SYS GMM, Jambi

\section{PENDAHULUAN}

Alokasi belanja merupakan salah satu cara fundamental daerah otonom untuk meningkatkan potensi pembangunan wilayah, meningkatkan pertumbuhan ekonomi, daya saing dan kemandirian. Pembangunan wilayah meliputi berbagai aspek diantaranya adalah pemenuhan kebutuhan dasar (basic need) dan penyediaan infrastruktur sosial maupun ekonomi. Pemerintah memiliki peran strategis dalam menjaga pertumbuhan ekonomi wilayah, karena dalam jangka pendek maupun jangka panjang ekonomi menjadi salah satu pilar pembangunan sosial. Dengan platform alokasi belanja yang efektif dan efesien, diproyeksikan pelaksanaan desentralisasi fiskal akan terwujud. Sinkronisasi antara alokasi belanja terhadap kegiatan ekonomi masyarakat ditunjukkan dengan pertumbuhan pendapatan perkapita regional yang tinggi dan ketimpangan pendapatan yang rendah. Alokasi belanja pemerintah merupakan salah satu bentuk investasi publik yang mendorong tumbuhnya nilai tambah (value added).

Desentralisasi fiskal menjadi masalah yang dihadapi sebagian besar daerah di Provinsi Jambi. Tiap-tiap daerah memiliki keterbatasan dalam pengelolaan keuangan daerah. Alokasi belanja pegawai semakin meningkat sedangkan alokasi belanja modal semakin menurun. Ketimpangan wilayah melalui 
indeks ketimpangan wilayah (Williamson indeks) setiap tahun semakin meningkat pada kategori tinggi. Ketergantungan pemerintah Kabupaten dan Kota semakin tinggi terhadap dana perimbangan. Fleksibilitas daerah sangat rendah serta lemahnya kapasitas pemerintah menggali sumber pendapatan yang hanya bergantung pada sektor pajak. Akibatnya, pertumbuhan ekonomi wilayah yang melambat ${ }^{1}$. Salah satu bentuk desentralisasi fiskal yang dilakukan oleh pemerintah pusat melalui dana perimbangan. Untuk jangka panjang transfer dana perimbangan akan berdampak buruk bagi kemandirian daerah. Tingginya ketergantungan daerah kepada pusat mencerminkan belum berhasilnya otonomi yang sudah diberikan.

Keberhasilan pembangunan daerah dilihat melalui kualitas hidup rakyat. IPM Provinsi Jambi secara nasional berada pada peringkat 17 dengan gambaran IPM Kabupaten dan Kota pada Tabel 1. Tabel 1 Perkembangan IPM Kabupaten/Kota di Provinsi Jambi Periode 2010-2015

\begin{tabular}{clcccc}
\hline \multirow{2}{*}{ No } & \multirow{2}{*}{$\begin{array}{c}\text { Indeks Pembangunan } \\
\text { Manusia (IPM) }\end{array}$} & \multicolumn{2}{c}{ Kategori* } \\
\cline { 3 - 5 } & Kabupaten/Kota & 2010 & 2015 & 2010 & 2015 \\
\hline 1 & Kab. Batanghari & 65.67 & 68.05 & Sedang & Sedang \\
2 & Kab. Bungo & 66.28 & 68.34 & Sedang & Sedang \\
3 & Kab. Kerinci & 65.16 & 68.89 & Sedang & Sedang \\
4 & Kab. Merangin & 63.85 & 67.15 & Sedang & Sedang \\
5 & Kab. Muaro Jambi & 62.84 & 66.66 & Sedang & Sedang \\
6 & Kab. Sarolangun & 64.64 & 68.10 & Sedang & Sedang \\
7 & Kab. Tanjung Jabung Barat & 61.49 & 65.03 & Sedang & Sedang \\
8 & Kab. Tanjung Jabung Timur & 62.84 & 66.66 & Sedang & Sedang \\
9 & Kab. Tebo & 63.62 & 67.29 & Sedang & Sedang \\
10 & Kota Jambi & 72.23 & 75.58 & Tinggi & Tinggi \\
11 & Kota Sungai Penuh & 69.91 & 73.03 & Sedang & Tinggi \\
\hline
\end{tabular}

Sumber BPS 2010-2015

*IPM $<60$ : IPM rendah, $60<$ IPM $<70$ : IPM sedang, $70<$ IPM $<80:$ IPM tinggi, IPM $<80$ : IPM sangat tinggi

Kualitas hidup rakyat dicirikan dengan Indeks Pembangunan Manusia (IPM). IPM mengukur capaian pembangunan manusia berbasis sejumlah komponen dasar kualitas hidup. Sebagai ukuran kualitas hidup, IPM dibangun melalui pendekatan tiga dimensi dasar. Dimensi tersebut mencakup umur panjang dan hidup sehat (a long and healthy life); pengetahuan (knowledge); dan standar hidup layak (decent standard of living). IPM merupakan data strategis karena selain sebagai ukuran kinerja Pemerintah, IPM juga digunakan sebagai salah satu alokator penentuan Dana Alokasi Umum (DAU) (BPS 2015). Dalam Peraturan Menteri Nomor 13 Tahun 2006, ketiga komponen IPM masuk dalam urusan wajib bagi pemerintah daerah.

Berdasarkan penjelasan diatas maka kajian ini bertujuan untuk menyusun strategi alokasi belanja pemerintah dalam meningkatkan IPM di Provinsi Jambi. Secara spesifik, penelitian ini bertujuan sebagai berikut.

1. Menganalisis perkembangan struktur alokasi belanja Pemerintah Daerah di Provinsi Jambi

2. Menentukan komponen belanja pemerintah yang berpengaruh terhadap IPM.

3. Merumuskan strategi belanja pemerintah yang dapat meningkatkan IPM.

\section{TINJAUAN PUSTAKA}

Pembangunan Manusia

Pembangunan manusia adalah suatu proses untuk memperbanyak pilihan-pilihan yang dimiliki oleh manusia. Pilihan yang terpenting adalah perluasan pilihan masyarakat (enlarge the people choice). Ada tiga pilihan yang paling mendasar yaitu untuk berumur panjang dan hidup sehat, untuk memperoleh pendidikan dan untuk memiliki akses terhadap sumber-sumber kubutuhan agar hidup secara layak. Apabila ketiga hal mendasar tersebut tidak dimiliki, maka pilihan lain tidak dapat diakses.

${ }^{1}$ KEKR Provinsi Jambi 2015 
Berdasarkan konsep pembangunan manusia, pendapatan merupakan salah satu pilihan yang harus dimiliki. Pembangunan bukan sekadar perluasan pendapatan dan kesejahteraan. Pembangunan manusia harus memfokuskan pada manusia. Untuk berumur panjang dan sehat, untuk berilmu pengetahuan dan untuk mempunyai akses terhadap sumber daya yang dibutuhkan agar dapat hidup secara layak.

UNDP (United Nations Development Programe) memperkenalkan penghitungan IPM metode baru dengan beberapa perbedaan mendasar dibanding metode lama. Terdapat dua hal mendasar dalam perubahan metode baru ini. Kedua hal mendasar terdapat pada aspek indikator dan cara penghitungan indeks. Pada metode baru, UNDP memperkenalkan indikator baru pada dimensi pengetahuan yaitu Harapan Lama Sekolah (Expected Years of Schooling). Indikator ini digunakan untuk menggantikan indikator AMH yang memang saat ini sudah tidak relevan karena capaian di banyak negara sudah sangat tinggi. UNDP juga menggunakan indikator PNB per kapita untuk menggantikan indikator PDB per kapita. Selain indikator baru, UNDP melakukan perubahan cara penghitungan indeks. Untuk menghitung agregasi indeks, digunakan rata-rata geometric (geometric mean). Cara penghitungan indeks yang terbilang baru ini cederung sensitif terhadap ketimpangan. Tidak seperti rata-rata aritmatik yang dapat menutupi ketimpangan yang terjadi antardimensi, rata-rata geometrik menuntuk keseimbangan ketiga dimensi IPM agar capaian IPM menjadi optimal.

\section{Kebijakan Fiskal untuk Pembangunan}

Jika Kebijakan finansial (moneter) terfokus pada uang, suku bunga, dan alokasi kredit, maka kebijakan fiskal terpusat pada segi penerimaan (perpajakan) dan pembelanjaan pemerintah (Todaro and Smith 2006). Keduanya merupakan wahana utama bagi peran aktif pemerintah di bidang ekonomi. Sebagian besar stabilitas makro ekonomi berfokus pada pengendalian dan pemotongan anggaran belanja pemerintah dalam rangka mencapai keseimbangan necara anggaran. Mobilisasi sumber daya untuk membiayai pembangunan publik yang terpenting tidak hanya difokuskan pada sisi pengeluaran, tetapi juga pada sisi penerimaan pemerintah. Pinjaman dalam dan luar negeri dapat digunakan untuk menutupi kesenjangan tabungan. Dalam jangka panjang, salah satu potensi pendapatan yang tersedia bagi pemerintah untuk membiayai segala usaha pembangunan adalah penggalakan pajak. Selain itu, ketiadaan pasar-pasar uang domestik yang terorganisir dan terkontrol dengan baik, sebagian besar pemerintahan negara-negara dunia ketiga memang harus mengandalkan langkah-langkah fiskal dalam rangka mengupayakan stabilitas perekonomian nasional dan memobilisasikan sumber-sumber daya (keuangan) domestiknya.

\section{Manajemen Penerimaan Daerah}

Manajemen penerimaan daerah sangat erat kaitannya dengan kemampuan pemerintah daerah dalam mengelola potensi fiskal daerah (Mahmudi 2010). Potensi fiskal daerah adalah kemampuan daerah dalam menghimpun sumber-sumber pendapatan yang sah. Berhasil tidaknya pemerintah daerah dalam memperoleh pendapatan daerah sangat dipengaruhi oleh sistem manajemen pendapatan yang digunakan. Prinsip dasar daerah dalam membangun sistem manajemen penerimaan daerah yaitu:

1. Perluasan basis penerimaan

Peningkatan pendapatan dapat dilakukan pada tataran kebijakan maupun perbaikan administrasinya. Upaya melakukan perluasan basis penerimaan merupakan salah satu bentuk peningkatan pendapatan melalui kebijakan. Yang dimaksud perluasan basis penerimaan adalah memperluas sumber penerimaan. Untuk memperluas basis penerimaan dapat dilakukan dengan cara berikut:

2. Pengendalian kebocoran pendapatan

Untuk mengoptimalkan perolehan pendapatan, pemerintah daerah harus melakukan pengawasan dan pengendalian yang memadai. Sumber-sumber kebocoran harus diidentifikasi dan segera diatasi. Kebocoran pendapatan bisa disebabkan karena penghindaran pajak (tax avoidance), penggelapan pajak (tax evasion), pungutan liar atau korupsi petugas.

3. Peningkatan efesiensi administrasi pajak

Efesiensi administrasi pajak sangat berpengaruh terhadap peningkatan kinerja penerimaan daerah. Masyarakat yang sebenarnya sudah memiliki kesadaran membayar pajak bisa jadi enggan membayar pajak karena alasan rumitnya mengurus pajak. Demikian pula investor yang ingin berinvestasi di daerah seringkali enggan masuk kerena hambatan birokrasi termasuk administrasi pajak yang berbelit-belit dan berbagai pungutan di daerah.

4. Transparansi dan akuntabilitas 
Akuntabilitas adalah mempertanggung jawabkan pengelolaan sumber daya serta pelaksanan kebijakan yang dipercayakan kepada entitas pelaporan dalam mencapai tujuan yang telah ditetapkan secara periodik. Implementasi konsep akuntabilitas dilakukan dengan pemeriksaan (audit) secara berkala atas laporan keuangan yang diterbitkan oleh pejabat/pengurus lembaga publik. Dengan adanya audit yang komprehensif, penyimpangan tersebut dapat diungkap dan dicarikan jalan keluar terbaik. Implementasi kebijakan desentralisasi dan otonomi daerah, terutama desentralisasi fiskal memerlukan adanya transparansi dan akuntabilitas.

\section{Manajemen Belanja Daerah}

Berdasarkan Peraturan Menteri Dalam Negeri Nomor 13 Tahun 2006 dan amademen Menteri Dalam Negeri Nomor 59 Tahun 2007, belanja pemerintah daerah adalah kewajiban pemerintah daerah yang diakui sebagai pengurangan kekayaan bersih dalam periode tahun anggaran bersangkutan. Pemerintah daerah harus mengalokasikan belanja secara adil dan merata agar dinikmati oleh seluruh kelompok masyarakat tanpa diskriminasi, khususnya dalam memberikan pelayanan umum. Dana yang diperoleh harus digunakan sebaik mungkin agar dapat menghasilkan peningkatan pelayanan dan kesejahteraan yang maksimal bagi masyarakat. Belanja daerah digunakan untuk pelaksanaan urusan pemerintah daerah yang menjadi kewenangan Provinsi atau Kabupaten/Kota yang terdiri dari urusan wajib dan urusan pilihan yang ditetapkan dengan ketentuan undang-undang. Berdasarkan UndangUndang Nomor 17 Tahun 2003 Pasal 16 Ayat 4 belanja daerah terdiri dari belanja pegawai, belanja barang, belanja modal, belanja subsidi, belanja hibah, dan belanja bantuan sosial. Belanja daerah berdasarkan Peraturan Pemerintah No 58 Tahun 2004 terdiri dari belanja pegawai, belanja barang dan jasa, belanja modal, belanja bunga, belanja subsidi, belanja hibah, belanja bantuan sosial, belanja keuangan, dan belanja tak terduga.

Belanja daerah berdasarkan Peraturan Menteri Dalam Negeri Nomor 13 Tahun 2006 adalah belanja menurut urusan pemerintah, belanja fungsi pemerintah, belanja menurut organisasi, belanja menurut program dan kegiatan, dan belanja menurut kelompok. Belanja pemerintah daerah menurut fungsi yang digunakan oleh pemerintah untuk tujuan keselarasan dan keterpaduan pengelolaan keuangan negara. Belanja pemerintah daerah menurut fungsi terdiri dari :

1. Belanja pelayanan umum adalah pengeluaran yang ditujukan dalam rangka peningkatan pelayanan umum pemerintah terhadap masyarakat maupun pihak swasta untuk pembayaran gaji, akses layanan atau perizinan, kemudahan informasi dan belanja operasional kebutuhan perkantoran sehari-hari.

2. Belanja fungsi ekonomi adalah pengeluaran yang digunakan untuk menciptakan lapangan pekerjaan, pembangunan sarana dan prasarana umum, serta memicu peningkatan kegiatan perekonomian masyarakat. Pengeluaran ini ditujukan agar mempunyai pengaruh langsung terhadap kesejahteraan masyarakat sekaligus mempunyai multiplier effect yang besar.

3. Belanja fungsi kesehatan adalah pengeluaran yang ditujukan untuk meningkatan kualitas kesehatan dan pelayanan seperti pembelian obat, fasilitas kesehatan dan gedung kesehatan.

4. Belanja fungsi pendidikan adalah pengeluaran yang ditujukan untuk meningkatkan kualitas pendidikan seperti pembelian buku, fasilitas jaringan internet sekolah maupun gedung sekolah.

5. Belanja fungsi ketertiban dan keamanan adalah pengeluaran yang ditujukan untuk menambah kekuatan dan ketahanan dalam mendukung ketahanan dan keamanan kondisi daerah.

6. Belanja fungsi pariwisata dan lingkungan hidup adalah pengeluaran untuk peningkatan kegembiraan atau hiburan bagi masyarakat seperti promosi dan pemeliharaan tempat wisata sekaligus dalam mempertahankan kelestarian dan kualitas lingkungan hidup adar tercipta kenyamanan

7. Belanja fungsi perlindungan atau jaminan sosial adalah pengeluaran untuk jaminan perlindungan masyarakat seperti penanganan bencana, permasalahan sosial dan lingkungan.

\section{Pengukuran Kinerja Laporan Keuangan}

Salah satu tujuan dan manfaat laporan keuangan adalah untuk memberikan informasi laporan keuangan sebagai pertimbangan pembuatan keputusan serta untuk pengukuran dan evaluasi kinerja. Pengukuran dan evaluasi kinerja keuangan dapat dilakukan dengan memanfaatkan data dan informasi dalam laporan keuangan yang dipublikasikan. Laporan keuangan yang dipublikasikan bersifat untuk umum bukan untuk memenuhi kebutuhan spesifik kalangan tertentu saja. Rasio keuangan yang dipergunakan untuk mengukur kinerja pemerintah daerah dalam struktur Anggaran Pendapatan dan Belanja Daerah (APBD) antara lain:

1. Derajat desentralisasi 
Rasio ini menunjukan menunjukan derajat kontribusi PAD terhadap total penerimaan daerah. Semakin tinggi kontribusi PAD maka semakin tinggi kemampuan pemerintah daerah dalam penyelenggaraan desentralisasi (Mahmudi 2013).

2. Rasio belanja pegawai

Tujuan penghitungan rasio Belanja Pegawai terhadap total Belanja Daerah adalah untuk mengetahui proporsi Belanja Pegawai terhadap total Belanja Daerah. Data Belanja Pegawai di sini adalah penjumlahan dari Belanja Pegawai langsung dan Belanja Pegawai tidak langsung. Rasio ini menggambarkan bahwa semakin tinggi angka rasionya maka semakin besar proporsi APBD yang dialokasikan untuk Belanja Pegawai. Begitu pula sebaliknya, semakin kecil angka rasio Belanja Pegawai maka semakin kecil proporsi APBD yang dialokasikan untuk Belanja Pegawai APBD

3. Rasio belanja modal

Porsi belanja modal dalam APBD merupakan komponen belanja yang sangat penting karena realisasi belanja modal akan memiliki multiplier effect dalam menggerakkan roda perekonomian daerah. Oleh karena itu, semakin tinggi angka rasionya diharapkan akan semakin baik pengaruhnya terhadap pertumbuhan ekonomi. Sebaliknya, semakin rendah angkanya, semakin berkurang pengaruhnya terhadap pertumbuhan ekonomi. Alokasi belanja modal terhadap total belanja daerah mencerminkan porsi belanja daerah yang akan dibelanjakan untuk membiayai belanja modal. Belanja modal ditambah belanja barang dan jasa merupakan belanja pemerintah daerah yang mempunyai pengaruh signifikan terhadap pertumbuhan ekonomi suatu daerah, disamping pengaruh dari sektor swasta, rumah tangga dan luar negeri.

4. Rasio belanja bantuan sosial

Belanja bantuan sosial merupakan salah satu pos dalam belanja tidak langsung. Secara definisi, bantuan sosial adalah pemberian bantuan yang sifatnya tidak secara terus menerus dan selektif dalam bentuk uang/barang kepada masyarakat atau organisasi profesi yang bertujuan untuk kepentingan umum. Dalam bantuan sosial ini termasuk didalamnya antara lain yaitu bantuan partai politik sesuai dengan peraturan perundang-undangan. Dari sisi pemerintah daerah bantuan sosial ini berpotensi menimbulkan tumpang tindih kegiatan dengan kegiatan yang dilakukan oleh satuan kerja perangkat daerah (SKPD) mengingat keduanya menggunakan dana dari APBD. Rasio Belanja Bantuan Sosial terhadap total Belanja Daerah mencerminkan porsi Belanja Daerah yang dibelanjakan untuk Belanja Bantuan Sosial. Semakin tinggi angka rasionya maka semakin besar proporsi APBD yang dialokasikan untuk Belanja Bantuan Sosial, demikian juga sebaliknya semakin kecil angka rasio Belanja Bantuan Sosial maka semakin kecil pula proporsi APBD yang dialokasikan untuk Belanja Bantuan Sosial.

\section{Panel Dinamis}

Seiring dengan dengan populernya model time series, muncul pemikiran untuk merumuskan metode data panel yang memasukkan lag dari peubah dependennya. Hal ini berakibat munculnya masalah endogeneity, sehingga bila model diestimasi dengan pendekatan fix effect maupun random effect akan menghasilkan penduga yang bias dan tidak konsisten. Untuk memecahkan masalah tersebut Arrelano dan Bond mengusulkan pendeketan method of moments atau yang biasa diseut dengan generalized method of mements (GMM). Dua estimasi GMM yang lazim digunakan yaitu first differences GMM (FD-GMM) dan System GMM. Pada estimasi menggunakan FD-GMM terutama bila terjadi korelasi antar lag dari pembedaan pertama, sehingga instrumen yang digunakan lemah. FD-GMM estimator bahkan akan lebih bias ke bawa dari pada fix effect, terutama bila jumlah periode waktu terbatas. Keterbatasan FD-GMM dapat dideteksi dengan membandingkan koefisien dari peubah lag yang diperoleh dari pendekatan PLS, FEM dan FD-GMM. Koefisien yang konsisten akan diperoleh nilai yang barada di antara PLS dan FEM.

Ide SYS GMM adalah mengestimasi sistem persamaan dari perbedaan pertama dan level pertama dan pada level, dimana instrument yang digunakan adalah pembedaan pertamanya. Dengan demikian SYS GMM estimator mengkombinasikan gugus persamaan level dengan perbedaan pertama sebagai instrument. Validitas dari tambahan instrumen ini dapat diketahui dengan menggunakan uji sargan untuk over-identifying instrument.

\section{Uji Sargan}

Uji Sargan digunakan untuk mengetahui validitas penggunaan peubah instrumen yang jumlahnya melebihi jumlah parameter yang diduga (kondisi overidentifying restriction). Hipotesisnya adalah:

H0: Kondisi overidentifying restriction dalam pendugaan model valid

$\mathrm{H} 1$ : Kondisi overidentifying restriction dalam pendugaan model tidak valid 


\section{Uji Arellano-Bond}

Komponen vi,t merupakan sisaan yang diasumsikan tidak mengalami autokorelasi, namun pada pendugaan dalam proses first difference diperoleh ( $\mathrm{vi}, \mathrm{t}-\mathrm{vi}, \mathrm{t}-1)$, sehingga $\mathrm{E}(\mathrm{vi}, \mathrm{t}, \mathrm{vi}, \mathrm{t}-1)$ tidak perlu bernilai nol. Namun untuk ordo selanjutnya untuk melihat konsistensi penduga GMM, tetap dikenai asumsi $\mathrm{E}\left(\mathrm{vi}, \mathrm{t}, \mathrm{vi}, \mathrm{t}_{-2}\right)=0$ atau tidak adanya autokorelasi antara vi,t dan vi,-2. Statistik Arellano-Bond digunakan untuk menguji konsistensi penduga yang diperoleh dari proses GMM. Hipotesisnya adalah:

H0: Tidak terdapat autokorelasi pada sisaan first difference orde ke-i

H1: Terdapat autokorelasi pada sisaan first difference orde ke-i

\section{Analytical Hierarchy Process}

AHP (Analytical Hierarchy Process) adalah salah satu bentuk pengambilan keputusan yang pada dasarnya berusaha menutupi semua kekurangan dari model-model sebelumnya. Peralatan utama dari model ini adalah sebuah hirarki fungsional dengan input utamanya persepsi manusia. Dengan hirarki, suatu masalah yang kompleks dan tidak terstruktur dipecah dalam kelompok-kelompoknya, kemudian diatur menjadi suatu bentuk hirarki.

Kelebihan dari AHP adalah kemampuannya jika dihadapkan pada situasi yang kompleks atau tidak terkerangka. Situasi ini terjadi jika data, informasi statistik dari masalah yang dihadapi sangat minim atau tidak ada sama sekali. Pengambilan keputusan dalam metodologi AHP didasarkan atas tiga prinsip dasar (Saaty 1993) yaitu:

a. Penyusunan Hirarki

Penyusunan hirarki permasalahan merupakan langkah untuk mendefinisikan masalah yang rumit dan kompleks, sehingga menjadi jelas dan rinci. Keputusan yang akan diambil ditetapkan sebagai tujuan, yang dijabarkan menjadi elemen-elemen yang lebih rinci hingga mencapai suatu tahapan yang paling operasional/terukur. Hirarki tersebut memudahkan pengambil keputusan untuk memvisualisasikan permasalahan dan faktor-faktor terkendali dari permasalahan tersebut. Hirarki keputusan disusun berdasarkan pandangan dari pihak-pihak yang memiliki keahlian dan pengetahuan di bidang yang bersangkutan.

b. Penentuan Prioritas

Prioritas dari elemen-elemen pada hirarki dapat dipandang sebagai bobot/kontribusi elemen tersebut terhadap tujuan yang ingin dicapai dalam pengambilan keputusan. Metode AHP berdasarkan pada kemampuan dasar manusia untuk memanfaatkan informasi dan pengalamannya untuk memperkirakan pentingnya satu hal dibandingkan dengan hal lain secara relatif melalui proses membandingkan hal-hal berpasangan. Proses inilah yang disebut dengan metode perbandingan berpasangan (pairwise comparison) untuk menganalisis prioritas elemen-elemen dalam hiaraki. Prioritas ditentukan berdasarkan pandangan dan penilaian para ahli dan pihak-pihak yang berkepentingan terhadap pengambilan keputusan, baik dengan diskusi atau kuesioner.

c. Konsistensi Logika

Prinsip pokok yang menentukan kesesuaian antara definisi konseptual dengan operasional data dan proses pengambilan keputusan adalah konsistensi jawaban dari para responden. Konsistensi tersebut tercermin dari penilaian elemen dari perbandingan berpasangan.

\section{METODE PENELITIAN}

\section{Jenis dan Sumber Data}

Jenis data yang digunakan dalam penelitian ini adalah data sekunder. Data sekunder tersebut merupakan data cross section dan time series. Data diperoleh dari Badan Pusat Statistik (BPS), Kementrian Keuangan, dan beberapa data pendukung lainnya. Untuk melakukan perhitungan pada beberapa variabel digunakan data hasil Susenas yang kemudian diolah sesuai dengan kebutuhan. Adapun data dan variabel yang digunakan dalam penelitian ini secara lebih lengkap ditunjukkan pada Tabel 2.

Tabel 2 Sumber data variabel

\begin{tabular}{ccc}
\hline Variabel & Keterangan & Sumber \\
\hline IPM & Indeks pembangunan manusia & BPS \\
Eco & Belanja sektor ekonomi & Kemenkeu (Realisasi Belanja Sektor \\
& Pelanja sektor Perumahan dan & Kemenkeu (Realisasi Belanja Sektor \\
PU & Fasilitas Umum & Kesehatan) \\
Health & Belanja Kesehatan & Kemenkeu (Realisasi Belanja Sektor \\
Edu & Belanja Pendidikan & Bansos) \\
\hline
\end{tabular}


Infrastruktur)

\section{Metode Analisis Data}

\section{Analisis Diskriptif}

Analisis deskriptif merupakan suatu metode analisis sederhana yang dapat digunakan untuk menggambarkan kondisi suatu observasi dengan menyajikannya dalam bentuk Tabel, grafik maupun narasi dengan tujuan untuk memudahkan pembaca dalam menafsirkan hasil observasi. Metode analisis deskriptif dalam penelitian ini digunakan untuk menggambarkan secara umum keragaan APBD, pertumbuhan APBD dan karakteristik fiksal 11 Kabupaten dan Kota di Provinsi Jambi periode 20102015. Beberapa rasio yang digunakan adalah:

1. Derajat Desentralisasi

$$
\text { Derajat Desentralisasi }=\frac{\text { Pendapatan Asli Daerah }}{\text { Total Pendapatan Daerah }} \times 100 \%
$$

2. Rasio Belanja Pegawai

$$
\text { Rasio Belanja Pegawai }=\frac{\text { Belanja Pegawai }}{\text { Total Belanja }} \times 100 \%
$$

3. Rasio Belanja Modal

$$
\text { Rasio Belanja Modal }=\frac{\text { Belanja Modal }}{\text { Total Belanja }} \times 100 \%
$$

4. Rasio Belanja Bantuan Sosial

$$
\text { Rasio Belanja Bantuan Sosial }=\frac{\text { Belanja Bantuan Sosial }}{\text { Total Belanja }} \times 100 \%
$$

\section{Analisis Model Regresi}

Model dapat didefinisikan sebagai suatu abstraksi atau penyederhanaan dari realitas (Juanda 2009). Pada penelitian ini analisis model regresi digunakan untuk menganalisis keterkaitan antara Indeks Pembangunan Manusia terhadap Belanja Pemerintah bidang ekonomi, belanja penyediaan perumahan dan fasilitas umum, belanja sektor kesehatan dan belanja disektor pendidikan. Pengolahan atas data dilakukan dengan menggunakan Stata 13. Model tersebut direpresentasikan dalam suatu persamaan matematika. Untuk mendapat model digunakan persamaan sebagai berikut:

$$
\ln I P M_{i t}=\alpha+\ln \alpha I P M_{i t-1}+\ln \alpha E c o_{i t-1}+\ln \alpha P U_{i t}+\ln \alpha H e a l t h_{i t}+\ln \alpha E d u_{i t}+\varepsilon_{i t}
$$

Tabel 3 Keterangan satuan variabel

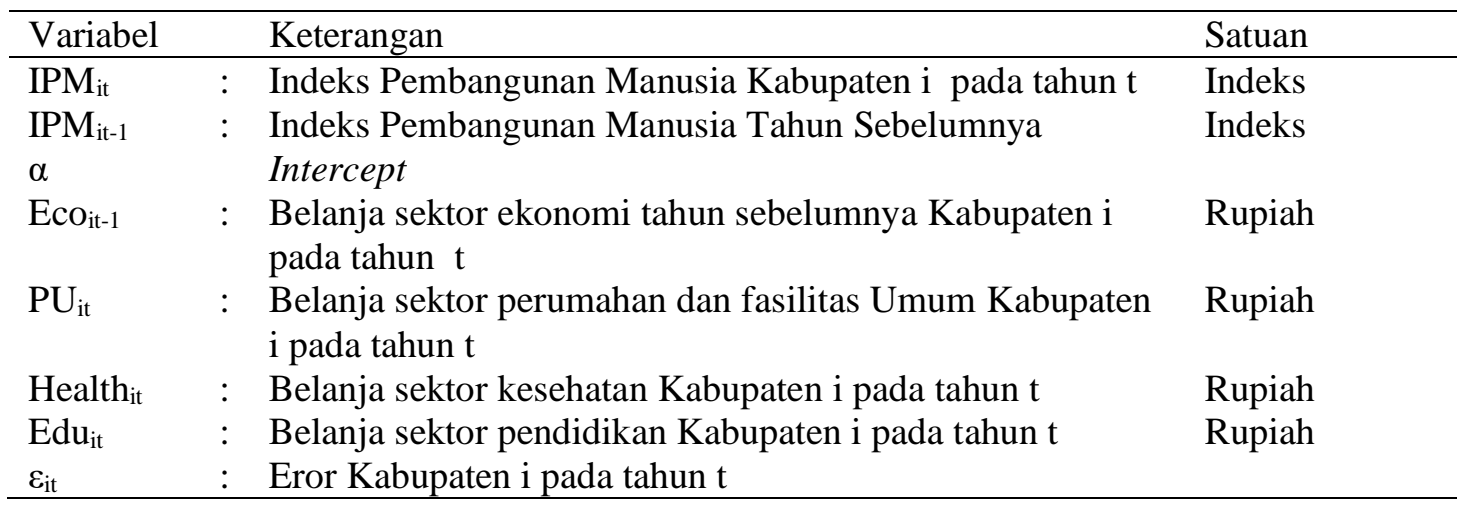

\section{Analisis AHP}

Perumusan strategi alokasi belanja kabupaten/kota di Provinsi Jambi menggunakan AHP (analytical hierarchy process). Model AHP memperlihatkan aplikasi elemen konsep optimisasi tujuan, variabel keputusan dan batasan pada nilai preferensi atas sejumlah alternatif pilihan yang terbesar, variabel analisis secara berjenjang dan batasan pilihan prioritas pada bangun modelnya (Dermawan 2005). Prinsip dasar dalam membangun model berjenjang atas variabel keputusan adalah membandingkan setiap variabel ditingkat bawah terhadap variabel di tingkat yang lebih tinggi. 


\section{HASIL DAN PEMBAHASAN \\ Analisis Pendapatan dan Belanja Daerah}

Analisis pendapatan dan belanja menggunakan agregat Kabupaten dan Kota dari tahun 2010 hingga 2015. Analisis yang digunakan yaitu tren pendapatan, tren belanja, derajat desentralisasi, rasio ketergantungan daerah, rasio kemandirian keuangan daerah. Perkembangan komponen pendapatan daerah secara umum mengalami peningkatan setiap tahunnya. Hal tersebut dapat dilihat dari Gambar 1. Total pendapatan pada tahun 2010 sebesar Rp 5.63 triliun dan pada tahun 2015 mencapai Rp 11.38 triliun. Peningkatan pendapatan mencapai dua kali lipat dari tahun 2010 (102.25 persen). Pertumbuhan pendapatan tertinggi pada periode tersebut adalah dari dana perimbangan rata rata sebesar 81.72 persen terhadap total belanja pertahun. Kemudian dari lain lain pendapatan yang sah rata-rata sebesar 12.26 persen terhadap total pendapatan pertahun. Untuk PAD memberikan porsi kontribusi yang kecil terhadap pendapatan daerah yaitu hanya sebesar 6.02 persen terhadap total belanja pertahun.

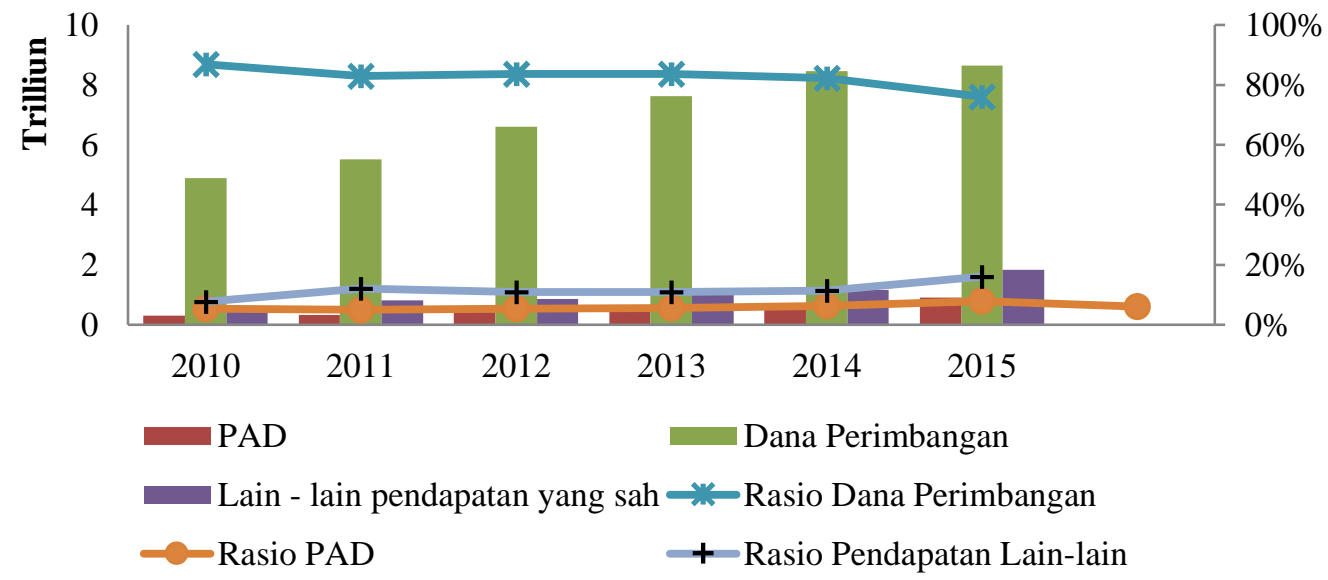

Gambar 1 Perkembangan pendapatan daerah

Peningkatan alokasi transfer diikuti dengan pertumbuhan belanja yang lebih tinggi. Hal ini dapat menunjukkan adanya indikasi bahwa peningkatan belanja yang tinggi tersebut dikarenakan inefesiensi belanja pemerintah. Untuk perkembangan komponen belanja daerah secara umum mengalami peningkatan. Hal tersebut dapat dilihat pada Gambar 2. Total alokasi belanja pada tahun 2010 sebesar Rp 6.11 triliun dan pada tahun 2015 mencapai 12.24 triliun. Total belanja tersebut meningkat dua kali lipat dari tahun 2010 (100.41 persen). Alokasi belanja terbesar pada periode tersebut adalah alokasi belanja pegawai.

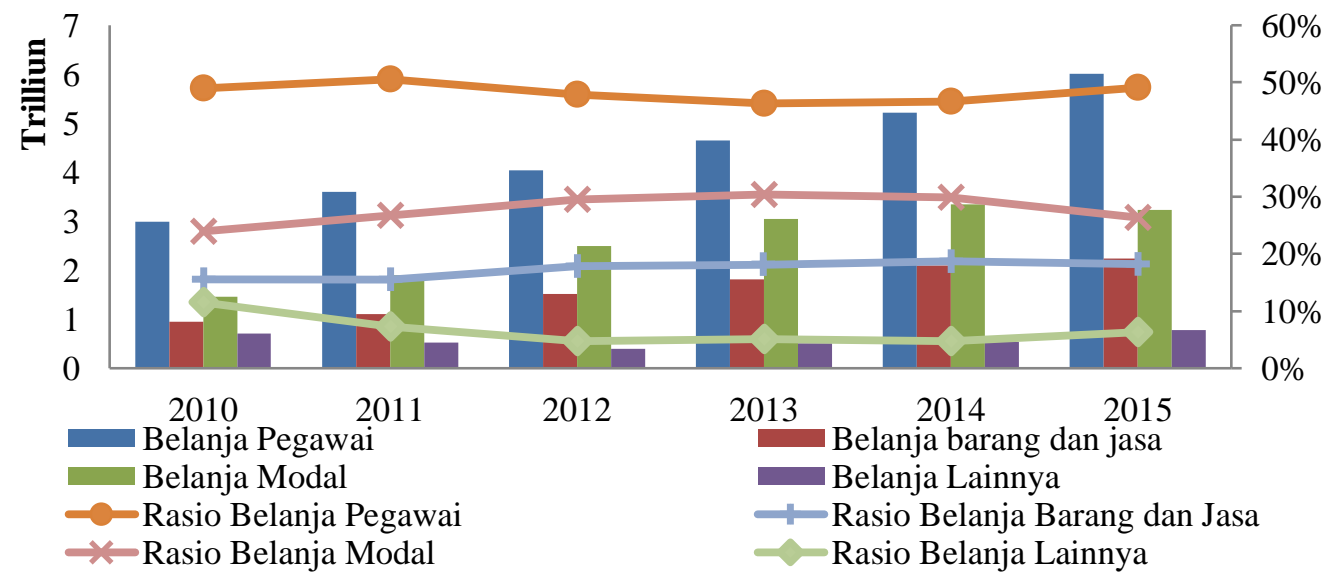

Gambar 2 Perkembangan belanja daerah

Rata-rata kontribusi belanja pegawai pertahun sebesar 48.23 persen pertahun dari total belanja. Selanjutnya belanja modal berkontribusi rata-rata sebesar 27.80 persen pertahun dari total belanja. Adapun belanja barang dan jasa rata-rata berkontribusi sebesar 17.34 persen pertahun. Untuk belanja lainnya rata-rata berkontribusi sebesar 6.62 persen dari total belanja. 


\section{Derajat desentralisasi}

Derajat desentralisasi dihitung berdasarkan perbandingan antar jumlah PAD terhadap total penerimaan daerah. Rasio ini menunjukkan derajat kontribusi PAD terhadap total Penerimaan daerah. Peningkatan kapasitas fiskal daerah sebagai bentuk upaya pemerintah daerah dengan menggali sumber-sumber PAD merupakan faktor yang sangat penting dalam menunjang efektivitas transfer pemerintah pusat kepada daerah (Amril, Erfit, and Safri 2015). Semakin tinggi kontribusi PAD maka semakin tinggi kemampuan pemerintah daerah dalam menyelenggarakan desentralisasi. Gambaran derajat desentralisasi Kabupaten dan Kota terlihat pada Tabel 4.

Tabel 4 Derajat desentralisasi

\begin{tabular}{lccc}
\hline Kabupaten/Kota & $2010(\%)$ & $2015(\%)$ & Status Desentralisasi \\
\hline Kab. Batanghari & 5.52 & 7.05 & Sangat Kurang \\
Kab. Bungo & 7.07 & 9.71 & Sangat Kurang \\
Kab. Kerinci & 4.31 & 6.46 & Sangat Kurang \\
Kab. Merangin & 5.88 & 6.23 & Sangat Kurang \\
Kab. Muaro Jambi & 3.27 & 5.65 & Sangat Kurang \\
Kab. Sarolangun & 5.23 & 4.80 & Sangat Kurang \\
Kab. Tanjung Jabung Barat & 4.41 & 5.64 & Sangat Kurang \\
Kab. Tanjung Jabung Timur & 2.90 & 3.03 & Sangat Kurang \\
Kab. Tebo & 6.06 & 5.70 & Sangat Kurang \\
Kota Jambi & 11.29 & 21.63 & Sedang \\
Kota Sungai Penuh & 0.99 & 5.09 & Sangat Kurang \\
\hline
\end{tabular}

Sumber DJPK 2010-2015

0.00\%-10.00\% sangat kurang; $10.01 \%-20.00 \%$ kurang; $20.01 \%-30.00 \%$ sedang; $30.01 \%-40.00 \%$ cukup; $40.01 \%-50.00 \%$ baik; >50.01\% sangat baik ${ }^{2}$

Tabel 4 memperlihatkan bahwa hampir secara keseluruhan daerah memiliki derajat desentralisasi yang sangat kurang. Hanya Kota Jambi pada tahun 2015 status desentralisasinya meningkat ke kategori sedang.

\section{Rasio belanja terhadap total belanja daerah}

Pada Tabel 5 memperlihatkan rasio belanja Kabupaten dan Kota di Provinsi Jambi. Rata-rata rasio belanja pegawai pemerintah kabupaten dan pemerintah kota di Provinsi Jambi terhadap total belanja APBD 2015 adalah sebesar 49.18 persen, yang ini berarti terjadi kenaikan dibandingkan dengan tahun 2014 sebesar 47.03 persen dan tahun 2014 sebesar 46.53 persen. Kota Jambi memiliki rasio belanja pegawai yang lebih tinggi sebesar 63.04 persen dari total belanja. Sedangkan kabupaten Tanjung Jabung Barat memiliki rasio belanja pegawai lebih kecil terhadap total belanja sebesar 43.49 persen.

\section{Rasio belanja modal terhadap total belanja daerah}

Pada Tabel 5 memperlihatkan rata-rata rasio belanja modal terhadap total belanja daerah sebesar 26.21 persen, yang berarti lebih rendah daripada tahun 2014 sebesar 29.51 persen serta tahun 2013 sebesar 30.11 persen. Dari rata-rata tersebut, terdapat 4 kabupaten dan 1 kota yang memiliki rasio belanja modal lebih besar dari rata-rata, sedangkan 5 kabupaten dan 1 kota memiliki rasio belanja lebih dibawah rata-rata.

Rasio belanja modal terbesar adalah pemerintah kabupaten Tanjung Jabung Barat (36.63 persen) dan pemerintah Kabupaten Muaro Jambi (34.85 persen). Sedangkan daerah yang memiliki rasio belanja modal terendah terhadap total belanja adalah pemerintah Kabupaten bungo (17.33 persen) dan pemerintah kota (18.76 persen).

Tabel 5 Rasio belanja terhadap total belanja

\begin{tabular}{lcccccc}
\hline \multirow{2}{*}{$\begin{array}{l}\text { Kabupaten } \\
\end{array}$} & \multicolumn{2}{c}{$\begin{array}{c}\text { Rasio Belanja } \\
\text { Pegawai (\%) }\end{array}$} & \multicolumn{2}{c}{$\begin{array}{c}\text { Rasio Belanja } \\
\text { Modal (\%) }\end{array}$} & \multicolumn{2}{c}{$\begin{array}{c}\text { Rasio Belanja } \\
\text { Bansos (\%) }\end{array}$} \\
\cline { 2 - 7 } & 2010 & 2015 & 2010 & 2015 & 2010 & 2015 \\
\hline Kab. Batanghari & 53.72 & 55.89 & 12.51 & 19.51 & 4.87 & 2.28 \\
Kab. Bungo & 47.01 & 58.27 & 24.85 & 17.33 & 0.19 & 0.00 \\
Kab. Kerinci & 55.44 & 51.76 & 16.10 & 18.76 & 0.77 & 0.53 \\
\hline
\end{tabular}

\footnotetext{
${ }^{2}$ Hanafi dan Mugroho (2005:80)
} 


\begin{tabular}{lcccccc}
\hline Kab. Merangin & 52.36 & 49.57 & 18.35 & 22.47 & 1.92 & 0.61 \\
Kab. Muaro Jambi & 52.84 & 54.26 & 20.75 & 34.85 & 1.68 & 0.41 \\
Kab. Sarolangun & 50.75 & 49.75 & 19.92 & 23.84 & 3.37 & 0.28 \\
Kab. Tanjung Jabung Barat & 46.91 & 43.49 & 29.32 & 36.63 & 1.40 & 0.28 \\
Kab. Tanjung Jabung Timur & 30.43 & 36.93 & 45.92 & 33.93 & 0.18 & 0.54 \\
Kab. Tebo & 37.47 & 44.78 & 35.18 & 33.49 & 0.47 & 0.00 \\
Kota Jambi & 67.72 & 63.04 & 9.43 & 20.42 & 0.90 & 0.13 \\
Kota Sungai Penuh & 47.70 & 46.20 & 25.87 & 27.07 & 0.64 & 0.16 \\
\hline
\end{tabular}

Sumber DJPK 2010-2015

\section{Rasio belanja bantuan sosial terhadap total belanja}

Dari Tabel 5 memperlihatkan bahwa rasio belanja bansos terhadap total belanja dibawah angka rata-rata agregat terdapat 5 Kabupaten yaitu Kabupaten Bungo, Kabupaten Tebo, Kabupaten Tanjung Jabung Barat, Kabupaten Sarolangun dan Kabupaten Muaro Jambi dan 2 Kota yaitu Kota Jambi dan Kota Sungai Penuh. Kabupaten Bungo dan Kabupaten Tebo untuk tahun 2015 tidak ada realisasi belanja bansos. Berbeda dengan tahun sebelumnya dimana 2 kabupaten tersebut memiliki anggaran belanja untuk belanja bantuan sosial dan rasionya terendah dibandingkan kabupaten dan kota lainya. Daerah yang memiliki rasio belanja bantuan sosial terhadap total belanja daerah terbesar adalah Kabupaten Batanghari, yaitu sebesar 2,28 persen dari total belanja.

\section{Komponen Belanja Pemerintah yang Berpengaruh Terhadap IPM}

Hasil estimasi pada Tabel 6 menunjukkan variabel yang berpengaruh signifikan terhadap IPM. Variabel IPM tahun sebelumnya menunjukkan Probabilitas sebesar 0.000 signifikan baik pada taraf nyata 1 persen, 5 persen atau 10 persen. Selain itu IPM tahun sebelumnya berpengaruh positif terhadap IPM tahun sekarang. Setiap kenakan IPM tahun sebelumnya sebesar 1 persen akan menaikkan IPM sekarang sebesar 0.9777218 persen. Variabel alokasi belanja disektor ekonomi tahun sebelumnya berpengaruh siginifikan terhadap IPM dengan probabilitas 0.039 lebih kecil pada taraf 5 persen. Selain itu alokasi belanja disektor ekonomi tahun sebelumnya berpengaruh positif terhadap IPM. Pertumbuhan ekonomi berkaitan erat dengan peningkatan barang dan jasa yang diproduksi dalam masyarakat, sehingga dengan semakin banyak barang dan jasa yang diproduksi, maka kesejahteraan masyarakat akan meningkat (Mirza 2011). Setiap kenaikan 1 persen alokasi belanja disektor ekonomi tahun sebelumnya akan menaikkan IPM sebesar 0.0030093 .

Tabel 6 Hasil Estimasi SYS GMM

\begin{tabular}{|c|c|c|c|c|}
\hline Parameter & Coef. & Std. Err & $\mathrm{P}>|\mathrm{z}|$ & \\
\hline $\operatorname{LnIPM}_{\mathrm{t}-1}$ & 0.9777218 & 0.0132464 & 0.000 & Vari \\
\hline $\operatorname{LnEco}_{\mathrm{t}-1}$ & 0.0030093 & 0.0014542 & 0.039 & abel \\
\hline $\mathrm{LnPu}$ & -0.0011683 & 0.0006383 & 0.067 & belanja \\
\hline LnHealth & -0.0008793 & 0.0014750 & 0.551 & pemerinta \\
\hline LnEdu & 0.0033461 & 0.0017031 & 0.074 & $\mathrm{~h}$ disektor \\
\hline \multicolumn{4}{|c|}{ Arrelano Bond (AB) Test } & perumaha \\
\hline \multicolumn{3}{|c|}{$\mathrm{z}$} & $\mathrm{P}>|\mathrm{z}|$ & $\mathrm{n}$ dan \\
\hline $\mathrm{AB} m 1$ & \multicolumn{2}{|l|}{-2.44870} & 0.0143 & sarana \\
\hline $\mathrm{AB} m 2$ & \multicolumn{2}{|l|}{-0.63529} & 0.5252 & fasilitas \\
\hline \multicolumn{4}{|c|}{ Sargan Test } & umum \\
\hline $\operatorname{chi} 2(13)$ & \multicolumn{2}{|l|}{9.87397} & & berpengar \\
\hline Prob > chi2 & \multicolumn{2}{|l|}{0.70420} & & \\
\hline
\end{tabular}

terhadap IPM dengan probabilitas sebesar 0.009 yang berarti lebih kecil dari alpha 1 persen. Belanja sektor perumahan dan sarana fasilitas umum berpengaruh negatif terhadap IPM dengan nilai jangka pendek sebesar -0.0011683 yang artinya setiap kenaikan alokasi belanja perumahan dan sarana fasilitas umum 1 persen akan menurunkan IPM sebesar 0.0011683 persen. Perkembangan belanja Kabupaten dan Kota meningkat setiap tahunnya namun porsi belanja lebih rendah dibandingkan belanja operasional. Kontribusi belanja modal tidak mencapai 30 persen dari total belanja. 
Perbandingan porsi belanja modal terhadap PDRB rata-rata hanya 2.05 persen sedangkan syarat idealnya belanja infrastruktur terhadap PDRB diatas 5 persen. Belanja infrastruktur belum maksimal mengadopsi ERR (economic rate of return) sehingga terjadi bias dalam pemanfaatannya. Variabel belanja kesehatan tidak berpengaruh signifikan terhadap IPM dengan probabilitas sebesar 0.551 lebih besar dari alpha 1 persen, 5 persen dan 10 persen. Variabel belanja sektor pendidikan berpengaruh signifikan terhadap IPM dengan probabilitas 0.074 lebih kecil dari alpha 10 persen. Alokasi belanja sektor pendidikan juga berpengaruh positif terhadap IPM sebesar 0.0033461. setiap kenaikan alokasi belanja disektor pendidikan akan menaikkan IPM sebesar 0.0033461 persen. Dalam jangka panjang ada hubungan antara pertumbuhan ekonomi dan pendidikan tinggi (Raluca 2015).

Konsistensi penduga ditunjukkan oleh hasil uji Arellano-Bond (AB). Hasil yang diperlihatkan berasal dari signifikansi nilai $m_{1}$ dan $m_{2}$. Statistik $m_{1}$ sebesar $\quad-2.44870$ dengan $p$-value (0.0143) signifikan pada taraf 5 persen dan 10 persen. Untuk statistic $m_{2}$ yang sebesar -0.63529 dengan $p$-value (0.5252) yang tidak signifikan baik pada taraf nyata 1 persen, 5 persen atau 10 persen. Hal ini menunjukkan penduga dikatakan konsisten.

Valid atau tidaknya suatu instrument bisa dilihat dari uji Sargan. Nilai Statstik uji sargan 9.87397 dengan probabilitas sebasar 0.70420 . probabilitas dengan angka tersebut tidak signifikan baik pada taraf nyata 1 persen, lima persen ataupun 10 persen. Hal ini bisa disimpulkan bahwa tidak terdapat masalah terhadap validitas instrument.

\section{Strategi Alokasi Belanja dalam Meningkatkan IPM di Provinsi Jambi}

Pada Gambar 3 memperlihatkan komponen yang paling penting dalam penentuan strategi. alokasi belanja yang menjadi prioritas utama adalah pertama yaitu alokasi belanja di sektor kesehatan (0.4660), yang kedua yaitu alokasi belanja di sektor pendidikan (0.4176), serta yang ketiga yaitu alokasi belanja disektor ekonomi. Jawaban dari para responden diperoleh bahwa strategi alokasi belanja di sektor kesehatan yang menjadi prioritas adalah alokasi belanja sarana dan prasarana pendukung (0.2824), alokasi belanja disektor pendidikan yang menjadi prioritas yaitu alokasi belanja dalam peningkatan kompetensi (0.2941), ketiga disektor ekonomi dalam meningkatkan IPM alokasi belanja sarana dan prasarana pendukung (0.2810).

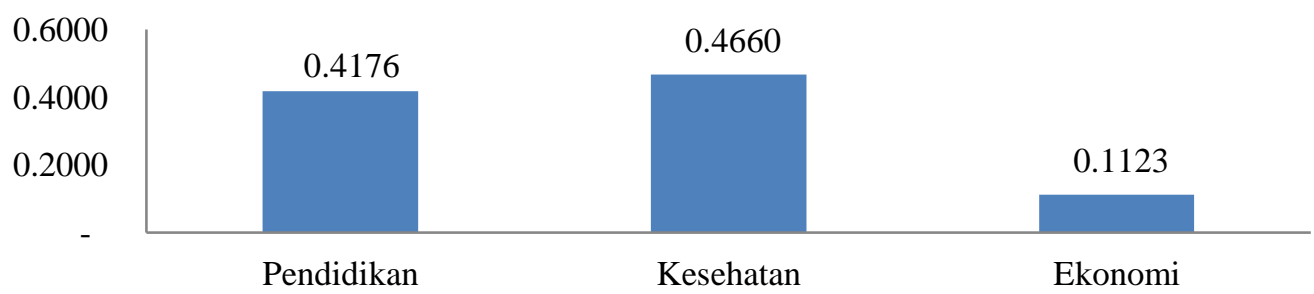

Gambar 3 Faktor yang Paling Dominan Dalam Strategi Alokasi Belanja Dalam Meningkatkan IPM

Pada Gambar 4 memperlihatkan kendala yang dihadapi pada bidang pendidikan, kesehatan dan ekonomi. Pada bidang pendidikan yang menjadi kendala adalah peningkatan kompetensi dengan nilai bobot sebesar 0.2941 . Kompetensi dalam bidang pendidikan yang menjadi ujung tombak adalah peran daripada tenaga pendidik. Tenaga pendidik harus menjadi sumber inspirasi bagi siswa. Tenaga pendidik yang memberikan rangsangan mental untuk siswa. Pada bidang kesehatan dan ekonomi kendala yang dihadapi adalah sarana dan prasarana pendukung dengan bobot masing-masing sebesar 0.2824 dan 0.2810 . 


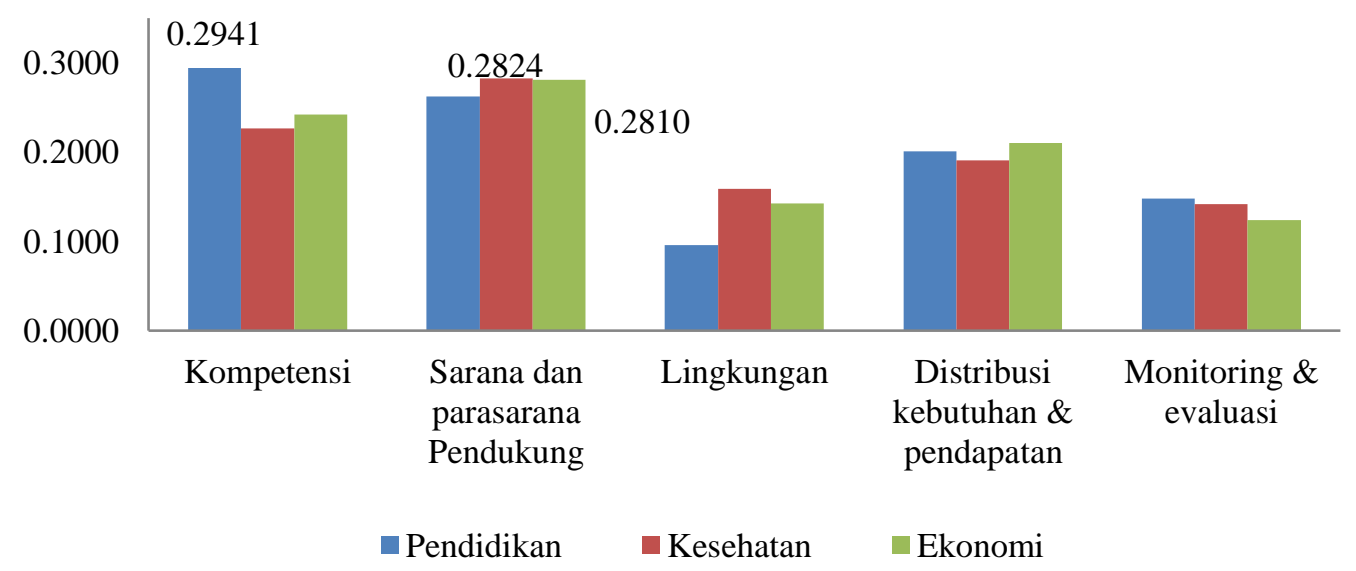

Gambar 4 Strategi alokasi belanja disektor pendidikan kesehatan dan ekonomi dalam meningkatkan IPM

Pada Gambar 5 memperlihatkan pemilihan strategi dalam meningkatkan IPM. Pada bidang pendidikan strategi yang dipilih adalah peningkatan kompetensi dan pelayanan (0.2431) Kompetensi tenaga pendidik dibagi menjadi 4 yaitu kompetensi pedagodik, kompetensi kepribadian, kompetensi sosial dan kompetensi professional.

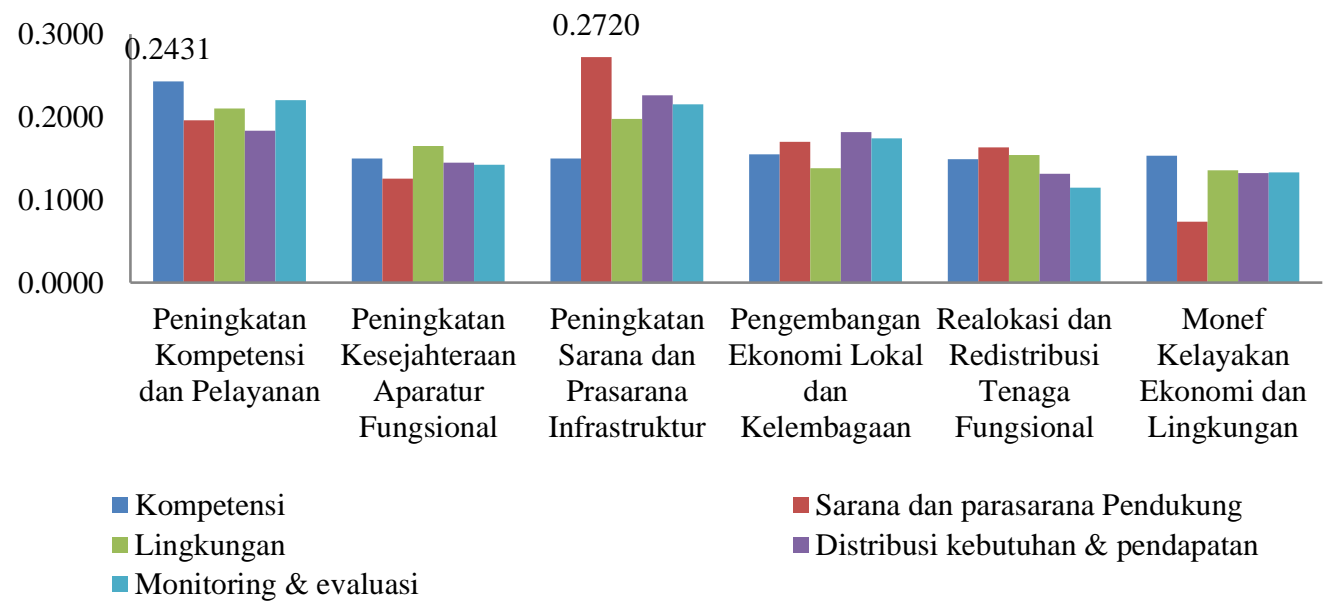

Gambar 5 Pemilihan strategi kebijakan dalam meningkatkan IPM

Bidang kesehatan dan ekonomi strategi yang menjadi pilihan yaitu peningkatan sarana dan prasarana infrastruktur dengan bobot 0.2720 . Peningkatan infrastruktur berupa peningkatan kapasitas pelayanan medis baik rumah sakit maupun puskesmas. Dibidang ekonomi adalah peningkatan sarana dan prasarana infrastruktur menjadi kedala utama. Layanan penyediaan listrik telah menjadi ukuran standar kelayakan hidup dan menopang kehidupan sosial (Niu et al. 2013). Pembangunan di bidang infrastruktur memainkan peran strategis dalam memproduksi berpenduduk besar dalam ekonomi dengan pertumbuhan pedesaan dan pertanian. Industrialisasi yang progresif dan efektif membutuhkan sebuah ekonomi primer dasar yang kuat, di mana sektor pertanian memainkan peranan yang sangat penting (Selebogo and LA 2013).

\section{KESIMPULAN DAN SARAN \\ Kesimpulan}

Porsi APBD kabupaten dan kota secara agregat menunjukkan masih besarnya ketergantungan pemerintah daerah terhadap pemerintah pusat. Tren APBD 2010 hingga 2015 anggaran pendapatan yang diperoleh dari pendatan asli mengalami pertumbuhan yang lebih tinggi daripada dana perimbangan. Anggaran belanja juga mengalami kenaikan dan didominasi oleh belanja pegawai. Rasio belanja pegawai terhadap total belanja masih tinggi hampir mencapai 49.18 persen sedangkan belanja modal terhadap total belanja 26.21 persen. 
Belanja pemerintah kabupaten dan kota yang berpengaruh terhadap IPM adalah alokasi belanja disektor ekonomi tahun sebelumnya dan belanja disektor pendidikan. Adapun alokasi belanja disektor perumahan dan sarana fasilitas umum berpengaruh negatif terhadap peningkatan IPM.

Penyusunan strategi alokasi belanja dalam meningkatkan IPM diprioritaskan pada sektor kesehatan. Dari alokasi belanja dibidang kesehatan dan ekonomi perlunya alokasi belanja disektor sarana dan prasarana pendukung, sedangkan disektor pendidikan perlunya alokasi dalam kompetensi dan pelayanan.

\section{Saran}

Berdasarkan kesimpulan hasil penelitian dapat direkomendasikan beerapa usulan kebijakan sebagai berikut:

1. Memperbesar ruang riskal daerah agar belanja pemerintah daerah lebih fleksibel. Upaya awal dengan efesiensi belanja pegawai, perampingan organisasi sesuai kebutuhan prioritas dan penetapan prioritas belanja pegawai. Walaupun belanja pegawai sifatnya mengikat, tetapi pengalokasiannya terdapat pos-pos belanja yang dapat ditentukan skala prioritasnya. Upaya selanjutnya dapat dilakukan dengan menggali sumber pendapatan asli daerah.

2. Merealokasikan belanja sektor perumahan dan sarana fasilitas umum serta alokasi belanja kesehatan ke sektor yang lebih berdampak positif terhadap IPM. Khususnya ke sektor ekonomi dan pendidikan yang nyata berpengaruh dalam meningkatkan IPM. Memaksimalkan kajian studi kelayakan ekonomi (ERR) pada tiap proyek yang diajukan.

3. Menyusun desain program kerja dan prioritas bidang pendidikan, kesehatan dan ekonomi. Bidang pendidikan penyusunan program peningkatan kompetensi dan pelayanan. Bidang kesehatan dan ekonomi penyusunan program penyediaan sarana dan prasarana infrastruktur.

\section{DAFTAR PUSTAKA}

Amril, Erfit, dan M Safri. 2015. "Flypaper Effect pada Kinerja Keuangan Kabupaten/Kota di Provinsi Jambi." Jurnal Perspektif Pembiayaan dan Pembangunan Daerah II(2015):135-146.

BPS. 2015. Indeks Pembangunan Manusia 2014. Jakarta: BPS.

Dermawan, Rizky. 2005. Model Kuantitatif, Pengembilan Keputusan \& Perencanaan Strategis. Bandung: Alfabeta.

Devas. 1989. Keuangan Pemerintah daerah di Indonesia. Jakarta, Jakarta: UI Press.

Firdaus, M. 2011. Aplikasi Ekonometrika Untuk Data Panel dan Time Series. Bogor: IPB Press.

Juanda, B. 2009. Ekonometrika, Permodelan dan Pendugaan. Bogor: IPB Press.

Mahmudi. 2010. Manajemen Keuangan Daerah. $1^{\text {st }}$ ed. Jakarta: Erlangga.

Mahmudi. 2013. Analisis Laporan Keuangan Pemerintah Daerah. $2^{\text {nd }}$ ed. Jakarta, Jakarta: Salemba.

Mirza, Denni S. 2011. "Pengaruh Kemiskinan, Pertumbuhan Ekonomi, dan Belanja Modal Terhadap IPM di Jawa Tengah.” Jejak IV(2011):102 - 113.

Niu, Shuwen, Yanqin Jia, Wendie Wang, Renfei He, Lili Hu, dan Yan Liu. 2013. "Electricity consumption and human development level : A comparative analysis based on panel data for 50 countries." Electrical Power and Energy Systems 53(2013):338-347.

Raluca, MD. 2015. "Education Determinant Economic Growth. Case of Romania." Academic World Education and Reasearch Center 404-412.

Saaty, TL. 1993. Pengambilan Keputusan bagi para Pemimpin : Proses Hirarki Analitik untuk pengambilan keputusan dalam situasi yang kompleks. Jakarta: Pustaka Binawan.

Selebogo dan Temitope LA. 2013. "Impacts of literacy rate and human development indices on agricultural production in South Africa." Agric. Econ. Czech (2013):531-536.

Todaro, MP and SC Smith. 2006. Pembangunan Ekonomi. $9^{\text {th }}$ ed. United Kingdom: Pearson Education Limited. 